\title{
The Use of ICT in Teaching Kiswahili Play in Secondary Schools in Uasingishu County, Kenya
}

\author{
Naumi Chepkemoi (MA) \\ Dr. David Wanyonyi
}

School of Education, Moi University, ELdoret, Kenya

doi: 10.19044/esj.2017.v13n25p150 URL:http://dx.doi.org/10.19044/esj.2017.v13n25p150

\begin{abstract}
The main aim of this study was to investigate the use of ICT in teaching Kiswahili plays in secondary schools as a way of cultivating interest and positive attitude towards drama at an early age. The objectives of the study were: To ascertain whether teachers of Kiswahili play have ICT skills for teaching Kiswahili plays and to examine attitude of teachers of Kiswahili towards integration of ICT in teaching Kiswahili plays The study used social learning theory by Bandura and the functionalism theory by John Dewey. The study employed a descriptive survey design to answer the research questions. Stratified sampling was used to categorize schools in to boys, girls, mixed schools, day and boarding schools. Simple random sampling was applied to select 275 students from a total of 918 students. The study used focus group discussion, questionnaires for teachers and students to collect data and interviews to provide further information on the teacher's attitude on the use of ICT in teaching Kiswahili play and observation. The study showed limited use of ICT in teaching and learning of Kiswahili play and it adds up into the pool of existing knowledge and is beneficial to teachers since it gives suggestion on the best combination to motivate and arouse interest of teaching and also to the teacher training institutions in preparing teachers to adequately use ICT in instruction in classroom level and also to the curriculum developers.
\end{abstract}

Keywords: Play, ICT, Teaching

\section{Introduction}

Kiswahili language in Kenya plays an important role as a national language and it contributes to the broad national goals of education in all aspects of life in Kenya. It is a compulsory subject in the national curricula of primary and secondary levels of education. Language is part and parcel of human life as it is the most effective means of human verbal communication. 
It is through language that people express their feelings, emotion, like and dislikes. Without language people would find it difficult to exchange ideas, share experiences and participate in cultural activities. While teaching Kiswahili play, the art of language is the key factor.

In Kenya the Ominde commission (1964) placed emphasis on the use of instructional resources for teaching. The commission called upon the ministry of education to avail the relevant instructional resources which could be used for teaching. ICT is expected to play a critical role in enhancing teaching and learning; it forms a vital ingredient in instructional process and ultimately reflects on student's performance. Since this is the age of digital the desire for quality is still on.

The digital technology has influence all aspects of human life, education is not an exceptional. Now the technology is in the process of change from digital to photon. Shortly photon technology will be available for the use of the society. In almost all countries in the region, teachers in primary, secondary and tertiary levels are being trained in the use of information and communication technologies (ICT) in education with varying degree and scope. Collis, and Pawlowski. Fishbein, and Ajzen (1995).

Over the past two decades, Information Technology (IT) has broadened to become Information and Communication Technology (ICT), and has become better established within schools Albirini, A. (2004).). Many claims have been made about its potential contribution to pupils' learning (Pachler, 1999) and official rhetoric has presented it as set to 'transform education' (Blair, 1997). Much current policy and practice reflects a technocratic determinism in which technology is seen unproblematic ally as providing relatively immediate tools for teachers and students, and its use as calling primarily for development of technical skills. However, others see successful educational applications of the computer as involving a complex interplay of context, people, activities, machines and available software within specific settings. While quality and level of ICT resource continue to improve in many schools, provision of equipment alone is likely to be of limited value unless more is understood about the interactions and processes engendered by using technology in different settings, and how pedagogical strategies to enhance students' learning might be developed effectively through them.

Students constitute a significant group within this social system, and their perspectives play an important part in framing the activity that takes place in school settings. Indeed, it has been argued that young people should be seen as active participants in shaping social and educational processes rather than viewed as passive recipients of them (Pollard \& Tann, 1993). Research has demonstrated that, from an early age, young people are capable 
of insightful and constructive analysis of their experience of learning in school and are able to comment on teaching approaches and contexts that are helpful in their learning (Brown \& McIntyre, 1993; Harris et al., 1995; McCallum et al., 2000; Rudduck \& Flutter, 2000). A key component in acquiring such understanding may be attention to the 'pupil voice' (Keys \& Fernandes, 1993; Blatchford, 1996; Rudduck et al., 1996). Rudduck and Flutter (op cit) maintain that 'we need to tune in to what pupils can tell us about their experiences and what they think will make a difference to their commitment to learning and, in turn, to their progress' (p. 75).

One of the best ways to develop teachers' ICT skills and promote ICT-pedagogy integration in their teaching is the provision of ICT-based training environments where on-demand access to materials, peers, and networks of experts where expertise and advices can be obtained and active discussion can take place in relation to 99 technology or pedagogy. In this regard, the approach of using ICT to support teachers' on-going professional development and networking can be very effective as long as organized support is provided (Pacey, 1999)

Education approaches in the $21^{\text {st }}$ century requires the integration of ICT in the delivery and access to the content. The use of computers in the teaching process has gave birth to the computer assisted instruction, computer managed instruction, computer based instruction (Heyes 1997).Prabhakar (1995)highlighted that use of ICT is more effective compared to the lecture method, but how will this be proved in regard to the use of ICT in teaching Kiswahili plays? It is this and related concerns that this research sought to answer.

\section{Problem Formulation}

The government of Kenya sought to embrace ICT with the hope that it will enable the country to improve and sustain development and poverty reduction.ICT has become common placed entity in all spheres of life. Over the past twenty years, the use of ICT has fundamentally changed the practice and procedures of nearly all forms of endeavourers (Misoi.j.2013). Education approaches in the $21^{\text {st }}$ century requires the integration of ICT in the delivery and access to the content and since play is a social oriented activity and has traditionally been associated with strong teachers having high degree of personal contact with learners and now that the world is moving rapidly into digital the role of ICT in instructing plays is becoming more important which will continue to grow and develop the subject in the $21^{\text {st }}$ century.

Research shows that the integration of ICT has not taken roots among the Kiswahili teachers compared to the science and computer related areas despite the government through the ministry of education trying to equip schools with computer facilities. The benefits of integrating ICT are many as 
indicated in other findings however the Kiswahili teachers have not fully realized the benefits and therefore the level is still low. Barak (2006) reveals that while teachers exploit ICT for their own learning, they are cautious about integrating advanced technologies in schools. The study also suggests that while teachers recognize the potential of technology in stimulating students' learning and making school studies relevant to real-life contexts, they do not think that ICT is preferable for class-based instruction for promoting cooperation and reflection in learning. Students of Kiswahili have not been performing well in Eldoret West Subcounty yet teachers are using other learning resources.

Use of ICT in teaching Kiswahili plays can improve the performance of Kiswahili in the district. The purpose of the present research was to investigate the extent to which secondary schools Kiswahili teachers' used ICT in teaching plays in the classroom level in Eldoret West sub county Uasin-Gishu County. The study sought to answer the following questions;

(i) What is the level of ICT skills do Kiswahili teachers have in teaching Kiswahili plays in secondary schools?

(ii) What are the teacher's attitudes towards the use of ICT in teaching Kiswahili plays?

\section{Background of ICT use}

There is an irreversible trend among countries in Asia and the Pacific to transform their teaching force and educational staff into technology literate and skilled workers. In almost all countries in the region, including emerging countries, teachers in primary, secondary and tertiary levels are being trained in the use of information and communication technologies (ICT) in education with varying degree and scope. (Coban, L. (2001).

While information and communication technology (ICT) is not a panacea for all educational problems, today's technologies are essential tools for $t$ teaching and learning. To use these tools effectively and efficiently, teachers need visions of the technologies' potential, opportunities s to apply them, training and just-in-time support, and time to experiment. Only then can teachers be informed and confident in their use of new technologies (Bowes, 2003). Teaching is becoming one of the most challenging professions in our society where knowledge is expanding rapidly and much of it is available to students as well as teachers at the same time (Perraton, Robinson, \& Creed, 2001).

As new concepts of learning have evolved, teachers are expected to facilitate learning and make it meaningful to individual learners rather than just to provide knowledge and skills. Modern developments of innovative technologies have provided new possibilities to teaching professions, but at 
the same time have placed more demands on teachers to learn how to use these new technologies in their teaching (Robinson \& Latchem, 2003)

In the recent years, there has been growing interest in the integration of information and communication technology (ICT) in the education systems of countries across the globe. Such interest has often been premised on the assumption that ICTs have a great potential for improving the quality of education. Moreover, education is presumed to cause socio-economic development. Indeed empirical studies confirm that education can make an important economic contribution (Kozman, 2005).

Successful integration of ICT in the teaching- learning process, among other things, is dependent on the preparation of teachers. In Tanzania, teachers are prepared at two major levels, the college and university levels. In the college level, graduates from ordinary level are trained as certificate teachers for pre - primary or primary schools while the advanced level leavers are trained as teachers for secondary schools. At the university level, depending on their Teachers' perceptions on ICT.

\section{Teachers' attitude towards the use of ICT}

Teacher perception is defined by Fishbein and Ajzen (1975) as a learned predisposition to respond to an object or class of objects in a consistently favorable or unfavorable way. In this case is the teacher's perception or attitudes or a state of mind or feeling towards of ICT in teaching and learning of Kiswahili language. Integration of ICT in teaching and learning process largely depend on teachers' perception that is a key factor in accepting their pedagogical practices or their actual use (Baylor \& Ritchie, 2002). According to Fishbein and Ajzen, (2013) teachers' perspectives about an object could be objectively true and mere opinions, prejudice or stereotypes. This could influenced by gender, education, training and profession, religious convictions, individuals' character, personality and even relationship with others.

A number of studies have been carried out to determine teachers' perspective about use of ICT in teaching and learning process. A study carried by Harrison and Rainer (1992), on ICT integration in teaching and learning process among the teachers teaching large universities in the Southern United States found out that many of them were less skilled in computer use and therefore had a negative attitude about it. Another study done by Albirini (2004) investigated the Science teachers' perspective about ICT integration in teaching and learning in Syrian high schools. The results indicated that Science teachers had a positive attitude towards integration of ICT in the teaching and learning process. Albirini (2004) also found out that majority of teachers in high schools in Syria were interested in developing 
their ICT skills and knowledge. Though the studies done in Harrison, Rainer and Albirini are very important to this work, they were done in developed countries and Science based subjects. Thethesis focuses on the teachers' perspective about integration of ICT in teaching and learning of Kiswahili plays in Kenyan secondary schools.

Palak and Walls (2009) conducted a mixed study to investigate whether teachers who frequently integrate technology and work at technology - rich schools shift their beliefs and practices toward a studentcentered paradigm. The results show ed that their practices did not change ; neither student- centered nor teacher - centered beliefs are powerful predictors of practices. However, teachers' attitudes toward technology significantly predict teacher and student technology use, as well as the use of a variety of instructional strategies Sang et al. (2010) focused on the impact of Chinese student teachers' gender, constructivist teaching beliefs, teaching self - efficacy, computer self- efficacy, and computer attitudes on their prospective ICT use. The findings confirmed the results of the study by Palak and Walls (2009) that the strongest predictor of future ICT use were teachers' attitudes toward it.

\section{Teachers' level of ICT skills}

One of the best ways to develop teachers' ICT skills and promote ICT-pedagogy integration in their teaching is the provision of ICT-based training environments where on-demand access to materials, peers, and networks of experts where expertise and advices can be obtained and active discussion can take place in relation to 99 technology or pedagogy. In this regard, the approach of using ICT to support teachers' on-going professional development and networking can be very effective as long as organized support is provided (Pacey, 1999)

Watts- Taffe et al. (2003) found that teachers can act as catalysts for the integration of technology through ICT. If the encouragement, equipment, and necessary technological support are available from institutes for the teachers, developing an ICT class will be easier for them. The main responsibilities of these teachers will be changing their course format, creating and explaining the new assignments, and arranging for the computer lab through their technology -learning specialists or assistants.

ICT-integrated training environments should be created to provide more effective ICT training. As it is indicated that, teachers tend to integrate ICT in their teaching if they experience ICT skills as a learner (Collis \& Jung, 2003) in his research show that many cases adopt ICT into their training process not just as content of the training but rather as an 
integrated training environment and thus allow teachers to experience ICTbased pedagogies.

Successful integration of ICT in the school system depends largely on the competence and on the attitude of teachers towards the role of modern technologies in teaching and learning. Thus, experienced teachers, newly qualified, and teachers need to be confident in using ICT effectively in their teaching (Kyriakidou, Chrisostomou, \& Bank, 2000). Simply having ICT in schools will not guarantee their effective use. Regardless of the quantity and quality of technology placed in classrooms, the key to how those tools are used is the teacher; therefore teachers must have the competence and the right attitude towards technology (Kadel, 2005).

There is a common saying that attitude determines altitude. Studies have established close links and affinities between teachers' attitude and their use of ICT. More positive attitudes towards the computer were associated with a higher level of computer experience (Dyck \& Smither, 1995; Teo, 2008). Teachers' behavior is a critical influence on students' confidence and attitude towards ICT as they provide important role model to their students (Derbyshire, 2003). The literature suggests that lack of adequate training and experience is one of the main reasons why teachers do not use technology in their teaching. This also eventuates in teachers' negative attitude towards computer and technology. In addition, lack of confidence leads to reluctance to use computers by the teachers (Kumar \& Kumar, 2003).

Attitude of pre-service and in-service teachers towards computer and technology skills can be improved by integrating technology into teacher education (Zammit, 1992). Findings have revealed that a significant relationship exist between computer attitude and its use in institutions for pre-service teachers (Khine, 2001), and also for serving teachers in the affective attitude, general usefulness, behavioral control, and pedagogical use (Yuen \& Ma, 2002).

\section{Research Methodology and Methods}

This study employed a descriptive research design. This design was considered appropriate for the study because it facilitate collection of a wide range of information or data from a large population with different characteristics and from different geographical background (Mc Burney 2007). Neuman 2007 echoed this view and suggested that it is a useful fact finding method, which determines and reports on things the way they are describes behavior, attitudes, opinions, perception and characteristics the way they are presented. 
Similarly Cohen and Manion (2008) observe that a survey research reports the status of issues of a particular time and applies it to the existing condition. This was applicable in the case because this study aimed at establishing the level of ICT use in teaching and learning Kiswahili literature plays in secondary schools. This is further supported by the fact that according to Neuman (2007) the design is appropriate for studies of this nature where the data sought does not have to be captured over several data collection round.

\section{Findings and Discussion}

This study was guided by the following objectives;

i. To investigate the level of ICT skills in Kiswahili play teachers.

ii. To examine the attitude of teachers of Kiswahili towards integration of ICT in teaching Kiswahili plays.

\section{Teachers level of ICT skills for teaching Kiswahili plays}

Findings on ICT in-service training attended by Kiswahili teachers indicated that 8 Kiswahili teachers (42\%) had attended ICT in-service course way back in 2011, the in-service course as highlighted by one of the teachers was that; It enlightened me on how to use ICT in teaching various aspect of Kiswahili literature. However, 11 (58\%) had never attended any in-service course since their professional training giving no reason at all. Killen (2000) righty asserts that any profession including teaching requires their worker to continue his/her education throughout his or her working life. This includes attending workshops, short courses and in-service to get new ideas gain more knowledge and improve competency in specific teaching and learning areas.

\section{In-service Training on Ict}

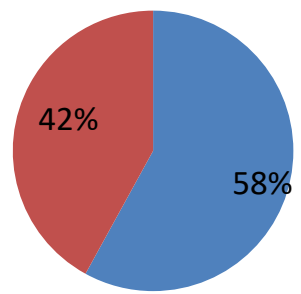

Never Attended

Attended

Figure 1: Shows Findings on ICT In-Service Training Attended By Kiswahili Teachers

The study was also concerned with the extent at which teachers were comfortable with the use of ICT facilities in teaching Kiswahili play and the findings are summarized in the following table. 


\begin{tabular}{|c|c|}
\hline ICT FACILITIES & PERCENT \\
\hline CDs & $37.5 \%$ \\
\hline DVDs & $37.5 \%$ \\
\hline PowerPoint & $10 \%$ \\
\hline Social media & $15 \%$ \\
\hline Internet & $0 \%$ \\
\hline Smart boards & $0 \%$ \\
\hline Total & $100 \%$ \\
\hline
\end{tabular}

Table 1: Extent At Which Teachers Were Comfortable With The Use of ICT In Teaching Kiswahili Play

The results imply that Kiswahili play teachers have not fully embraced integration of ICT in their teaching and learning activities of the plays. Most of the play teachers were comfortable in using CDs and DVDs materials from KIE with a percentage of $37.5 \%$ respectively, only $10 \%$ used power point presentation, and $15 \%$ used social media for their own benefits. The level of usage indicates that although Kiswahili play teachers use CDs and DVDs, still there is need to integrate other ICT facilities in their teaching and learning activities to improve the quality of the content delivery.

\section{Teachers attitude on integration of ICT in teaching Kiswahili plays}

The study also sought to find out the attitude of the teachers regarding the use of ICT in teaching and learning Kiswahili plays. The findings showed that 13 teachers $(68.4 \%)$ agreed that effective use of ICT facilities is vital for encouraging and facilitating students learning and only 6 teachers (31.6\%) disagreed, 14 teachers $(73.7 \%)$ agreed that through the use of ICT subject content can be more carefully selected and organized, 4 teachers (21\%) disagreed and one teacher (5.3\%) was undecided, 15 teachers (79\%) agreed that delivery of instruction is much more standardized as learners with varying ability can receive the same message and their individual differences catered for using plays and only 4 teachers $(21 \%)$ disagreed, 15 teachers (79\%) agreed that through ICT usage in practice, teaching can be much more interesting and enjoyable only 4 teachers (21\%) disagreed, 13 teachers (68.4\%) agreed that ICT use promotes student interaction, student-teacher interaction and teacher-student interaction only 6 teachers $(31.6 \%)$ disagreed, 13 teachers agreed that ICT also saves teaching time as it requires a short time to present a lot of information and only 6 teachers $(31.6 \%)$ disagreed, $14(73.7 \%)$ teachers agreed that ICT facilities can be used to reveal needs and stimulate students interest and questions, at the same time only 5 (26.3\%) disagreed. The findings indicated that (100\%) all teachers have ever in one point underwent an ICT training and they had a positive attitude towards ICT use but due to resistance to change they have 
rarely or never used ICT in the teaching of Kiswahili plays in the classroom level as shown in the table below.

Table 2: Teachers Perception on Integration of ICT in Teaching Kiswahili Plays

Teachers Perception on Integration of ICT

\begin{tabular}{cccc}
\hline Statement & Agreed & Disagreed & Undecided \\
\hline $\begin{array}{c}\text { Effective use of ICT facilities is vital for encouraging } \\
\text { and facilitating students learning }\end{array}$ & $68.4 \%$ & $31.6 \%$ & \\
$\begin{array}{c}\text { Through the use of ICT subject content can be more } \\
\text { carefully selected and organized. }\end{array}$ & $73.7 \%$ & $21 \%$ & $5.3 \%$ \\
$\begin{array}{c}\text { Delivery of instruction is much more standardized as } \\
\text { learners with varying ability can receive the same } \\
\text { message and their individual differences catered for } \\
\quad \text { using plays }\end{array}$ & $68.4 \%$ & $31.6 \%$ & \\
$\quad \begin{array}{c}\text { ICT usage in practice, teaching can be much more } \\
\text { interesting and enjoyable. }\end{array}$ & $79 \%$ & $21 \%$ & \\
$\begin{array}{c}\text { ICT use promotes student interaction, student-teacher } \\
\text { interaction and teacher-student interaction. }\end{array}$ & $68.4 \%$ & $31.6 \%$ & $31.6 \%$ \\
$\begin{array}{c}\text { ICT also save teaching time as it requires short time } \\
\text { to present a lot of information. }\end{array}$ & $68.4 \%$ & \\
\hline
\end{tabular}

\section{Conclusion}

The study found that the use of ICT in teaching of Kiswahili play has not taken roots among the teachers despite the government trying to equip schools with computer facilities. That shows they have not realize the benefits of the integration of ICT in teaching and learning. It has become appealing obvious that our technology has exceeded our humanity, (Misoi J.K .2013).

There is need for Kiswahili play teachers to embrace and fully adopt use of ICT in their teaching and learning activities in secondary schools in order to enjoy the benefits of ICT in schools and to meet the national goals of education and vision 2030. Therefore Kiswahili play teachers should change their attitude and should be ready to be trained to ensure that they have the right skills to integrate ICT in their teaching and learning activities. This may increase focus on interaction between teachers and their students leading to improved quality of education.

\section{References:}

1. Albirini, A.A (2004). Teachers' Attitudes toward Information and Technology. The case of Syrian EFL Teachers. Journal of Computers and Education, 47,373-398.

2. Fishbein, M. \& Ajzen, I. (1995) Understanding attitudes and predicting social behavior. Englewood Cliffs, NJ: Prentice- Hall.

3. Barak (2006). The intergration of ICT in teaching and learning 
4. Baylor, A.L. \& Ritchie, D.(2002). 'What factors facilitate teacher skill, morale and perceived student learning in technology use in the classrooms?' Computers and Education.

5. Blair, (1997). A Review of the Research Literature on Barriers to the Uptake of ICT by Teachers. British Educational Communications and Technology Agency.

6. Blatchford, (1996). Educational research: An introduction ( $8^{\text {th }}$ ed) omazon.com

7. Bowes, (2003). Instructional Design. Principals and Applications. New York:Englewood Cliff.

8. Brown \& McIntyre, (1993). Key past and current initiatives supporting the use of ICT in schools in African Commonwealth countries.

9. Collis \& Jung, (2003). Development of an instrument to measure preservice teachers' technology skills, technology beliefs, and technology barriers. Computers in the Schools, vol. 25, pp.112 - 125.

10. Collis, B. \& Pawlowski, J. (2001). Flexible learning in a digital world: Experiences and expectations. London: Kogan Page.

11. Coban, L. (2001). Oversold and Underused: Computers in the Classroom. Cambridge. Harved University Press.

12. Collis, B, \& Pawlowski. Fishbein, M. \& Ajzen, I. (1995). Belief, Attitude, Intention and Behavior Reading, MA: Addison. Wesley Publishing Company, Inc.

13. Dyck, J. L. \& Smither, J. A. (1995). Older adults' acquisition of word processing. The contribution of cognitive abilities and computer anxiety. Computer in Human Behavior, 12 (1), 107-199.

14. Harris et al., (1995). Producing Teaching materials: A handbook for Teachers and trainers. London: Kogan

15. Harrison and Rainer (1992). National policy for using ICT to support teaching and learning in primary and secondary schools in East Africa.

16. Heyes (1997). 'Teacher pedagogical beliefs: The final frontier in our quest for technology integration?', Educational Technology Research and Development vol. 53, no. 4, pp. 25- 39.

17. Kadel, R. (2005, February). How teacher attitude affect technology. Learning and Leading with Technology, 39 (5), 34-47.

18. Keys \& Fernandes, (1993). An analysis of the primary school teachers' usage of instructional software. International Journal of Emerging Technologies, 3 (1), 45-53.

19. Khine, M. S. (2001). Attitudes toward computers among teacher education students in Brunei 
20. Kozman, 2005). Factors influencing the success of computer skills learning among in-service teachers. British Journal of Educational Technology, 28, 139-141.

21. Kumar, P. \& Kumar A. (2003). $\quad$ Effect of a web-based project on preserves and in-service teachers' attitudes toward computers and technology skills. Journal of Computing in Teacher Education, 19(3), 87-92.

22. Mc Burnei H.D and Theresa L.White (2007). Research methods.Delhi.Akash press.

23. McCallum et al., (2000). Will new teachers be prepared to teach in a digital age? Santa Monica. Milken Family Foundation.

24. Misoi.j. (2013). Importance of ICT in education v0l.2

25. Neuman,L.W.(2007). Basics of social Research: Qualitative and quantitative approaches. Boston: Allyn and Bacon.

26. Pacey, (1999). School Radio programmes: A Case study of its use in selected institutions in Nyanza Provinced Kenya. Unpublished MPHil Thesis: Wales: Great Britain

27. Pachler, (1999). A survey of Resources available for Teaching Reading in English in Secondary schools in Kenya. Unpublished M.Ed Thesis: Eldoret: Moi University

28. Palak, D. and Walls, R. T. 2009. Teachers' beliefs and technology practices: A mixed- methods approach, Journal of Research on Technology in Education, vol. 41, pp.157 - 181.

29. Perraton, Robinson, \& Creed, (2001). The development of information technology skills in trainee teachers for further education sector. Research in Post-Compulsory Education, 3 (2), 240-251.

30. Sang et al. (2010). Fostering girls' computer through laptop learning - Can mobile computers help to level out the gender difference? Retrieved 17 July 2008 from

31. Teo, (2008). United Nations Educational, Scientific and Cultural Organization (2008a). ICT competency standards for teachers: Policy framework. United Kingdom: Author. Retrieved 23 January 2009 from http://www.oei.es/tic/competencias_tic_docentes_marcos_politicas.p df

32. Watts- Taffe, S., Gwinn, C. B. and Horn, M. L., 2003. Preparing preserves' teachers to integrate technology with the elementary literacy program. The Reading Teacher, vol. 5.

33. Zammit, S. A. (1992). Factors facilitating or hindering the use of computers in schools. Educational Research, 34, 57-66. Correspondence: Mudasiro O. Yusuf, Associate Professor of 
Educational Technology, Department of Science Education, Faculty of Education, University of Ilorin, Kwara State, Nigeria. 